\title{
Physiological responses to rock climbing in young climbers
}

\author{
Audry Birute Morrison, Volker Rainer Schöffl
}

Br J Sports Med 2007;41:852-861. doi: 10.1136/bjsm.2007.034827

Key questions regarding the training and physiological qualities required to produce an elite rock climber remain inadequately defined. Little research has been done on young climbers. The aim of this paper was to review literature on climbing alongside relevant literature characterising physiological adaptations in young athletes. Evidence-based recommendations were sought to inform the training of young climbers. Of 200 studies on climbing, 50 were selected as being appropriate to this review, and were interpreted alongside physiological studies

highlighting specific common development growth variables in young climbers. Based on injury data, climbers younger than 16 years should not participate in international bouldering competitions and intensive finger strength training is not recommended. The majority of climbing foot injuries result from wearing too small or unnaturally shaped climbing shoes. Isometric and explosive strength improvements are strongly associated with the latter stages of sexual maturation and specific ontogenetic development, while improvement in motor abilities declines. Somatotyping that might identify common physical attributes in elite climbers of any age is incomplete. Accomplished adolescent climbers can now climb identical grades and compete against elite adult climbers aged up to and $>40$ years. High-intensity sports training requiring leanness in a youngster can result in altered and delayed pubertal and skeletal development, metabolic and neuroendocrine aberrations and trigger eating disorders. This should be sensitively and regularly monitored. Training should reflect efficacious exercises for a given sex and biological age.

See end of article for authors' affiliations

Correspondence to: Audry Birute Morrison, 302 Clive Court, Maida Vale, London W9 1SF, UK audrym@gmail.com

Accepted 19 April 2007 Published Online First 22 May 2007
$\mathrm{R}$ ock climbing is both a physical and psychologically demanding aesthetic sport. Only very small parts of the hands and feet are in contact with the climbing surface whether climbing vertically upwards or more horizontally on an overhanging route as seen in fig $1 .{ }^{1}$ Elite-level rock climbing places extreme forces on the upper body extremities, specifically digital and upperextremity strength. ${ }^{2-5}$ Relative strength is high in elite climbers as they must support and lift their body mass using a variety of finger grips, combined with complex vertical and lateral movement and position changes. ${ }^{2-13}$

Psychologically, the climber must manage the arousal of climbing a demanding and/or unknown route while puzzling out the most efficient technical moves required to minimise the intrinsic risk of falling or injury. ${ }^{53-16}$ Completing an unknown route first time without falling is referred to as an "onsight" ability, and is essential for competition. "Redpointing" refers to completion of a route after several attempts. Jean Piaget's distinguished research places the developmental ability to solve abstract and formal problems between the ages of 11 to 15 years. ${ }^{17}$

Climbers typically seek out new route challenges to develop honed technical skills whether on artificial rock surfaces indoors or outdoors on specific rock types. The constant challenge of climbing unknown routes is extended to competitions where all the routes will be unknown to the competitor and cannot be rehearsed or specifically trained for. Little research has explored the psychological or neurogenic requirement of rock climbing at any age, though the former is a key element in accomplished climbers. ${ }^{13} 15161819$ The scope of this paper is restricted to the physiological aspects of climbing.

\section{HISTORY AND AGE CATEGORIES OF COMPETITIVE CLIMBING}

Rock climbing originated as a skill practice to train for short difficult sections of a long Alpine ascent. It has progressed to burgeon many new subdisciplines such as technical difficulty climbing, speed climbing, bouldering and ice climbing. ${ }^{5} 20$

Two decades of sport climbing competitions in Europe and the former Soviet Union have secured rock climbing's inclusion as an extra-curricular sport in many countries. ${ }^{20}$ The International Mountaineering and Climbing Federation (UIAA) arranged the first successive annual World Cup Climbing event in 1989 and participation in the 2005 International World Games Association. ${ }^{20} 21$ In 2006 the UIAA endorsed the creation of an International Federation to regulate competition climbing to meet Olympic Games requirements. ${ }^{20}$

Watts $^{5}$ suggests that the most talented climbers in the last decade have been relatively young, though age was not specified. The 2006 male and female European senior climbing championship winners were aged 16 years, an age that can also found among adult World Cup finalists. ${ }^{22}$ Competitive climbing in some countries can feature unusually broad and overlapping age ranges. For example, one competition featured categories for: juniors aged 13-15 years, masters open to any age, open competition $\geqslant 16$ years and mixed veterans aged $\geqslant 45$ years. ${ }^{23}$ There is no known peak performance age in climbing (see table 1). This should not lead to the assumption that an adult's training regimen is suitable for a

Abbreviation: UIAA, International Mountaineering and Climbing Federation. 


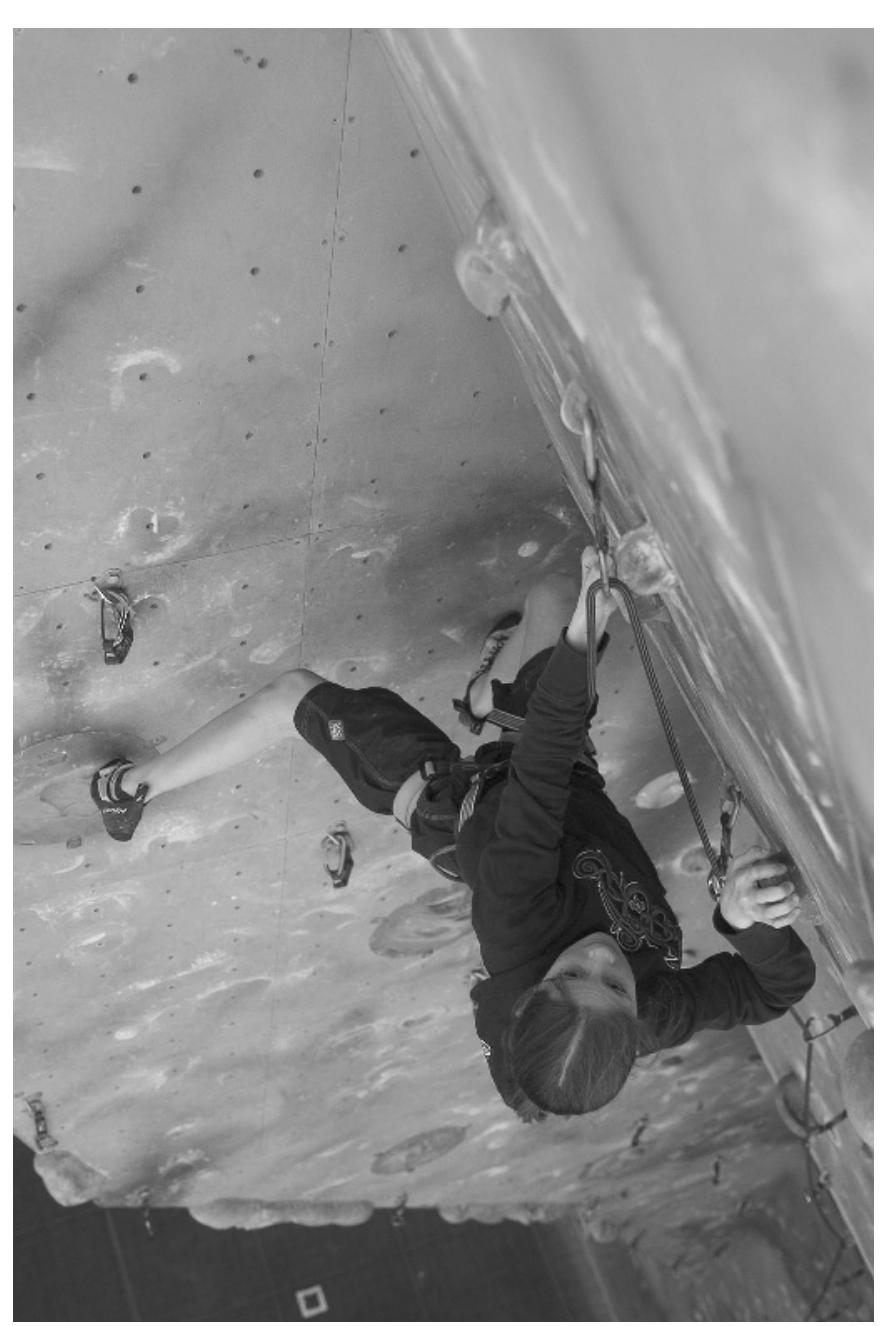

Figure 1 Female competition climber aged 13 years on an indoor lead climbing route. Informed consent was obtained for publication.

growing young climber. The term "youngster" in this review refers to those aged 7-17 years.

\section{LIMITATIONS OF EXISTING CLIMBING DATA}

The inherent nature of the sport presents a challenge in standardising testing protocols for specificity and sensitivity to climbing ability. ${ }^{4} 712131920$ 24-30 It combines dynamic gymnastic-like movements with static isometric position holds, explosive strength, stamina and intense isometric gripping function.

Table 1 summarises some of the difficulties posed when comparing studies. Climbing involves attempting new routes on different artificial or rock surfaces that are subjectively graded 515192025 and this grading system can vary among countries, ${ }^{19} 20$ the intensity of climbing exercise is influenced by a climber's training, ability and experience; 410111519283132 improved equipment and techniques continue to facilitate more technically difficult climbing that creates new higher grade abilities; ${ }^{53}$ and climbers are not necessarily brought to volitional fatigue..$^{25}$ 34-37 Performance terminating "climbing fatigue" is generally localised to the muscles responsible for gripping function. ${ }^{411} 1924252930$

A trained adult climber's heart has a similar cardiac response and morphological adaptation to that of a weight lifter as opposed to an aerobically led sport. ${ }^{38}$ It is characterised by a submaximal cardiac output, ${ }^{5} 19253839$ high heart rate $^{46122829343840}$ and marked increase in peripheral resistance. $^{19293841}$ This high isometric content of climbing prevents physiological data obtained from climbing exercise, for example blood lactate levels, from being directly compared with published isotonic exercise reference tables. ${ }^{411} 1234{ }^{36}$ Isometric exercise testing protocols are poorly related to dynamic athletic performance. ${ }^{4} 123542$ Direct physiological data comparisons between climbing studies with a unique experimental design cannot be made. ${ }^{1-5} 1012132425374143-46$

Sport-specific testing protocols with sensitivity and repeatability to common physiological variables in high-ability climbers are still being developed. ${ }^{4} 799^{10-13242627}$ For example, the use of handgrip dynamometry to measure handgrip strength is increasingly not used as a measured performance variable as it lacks specificity to climbing. ${ }^{1-3} 52627304041$

\section{SKELETAL, TENDON AND LIGAMENT GROWTH}

Growth is a complex biochemical and biological process whereby predetermined genetic expression is maximally achieved only when favourable conditions operate throughout the entire period of growth. ${ }^{45}{ }^{47-56}$ Developmental maturation of different tissues and bones occurs at different biological ages and is influenced by changes in endocrine function, especially during adolescence. ${ }^{45}{ }^{49-52} 57$ Load-bearing exercise, for example in climbing or gymnastics, is positively associated with increased bone mineral content and mass compared with normative data. ${ }^{31485859}$ Inadequate body fat in a youngster can detrimentally influence bone growth and development and will be explored later.

Full skeletal maturation to adult proportions and biological function are not achieved until approximately age 19-20 years in women and 22-23 years in men. Skeletal maturation ends with epiphyseal closing once three distinct stages in linear growth have been achieved..$^{45} 4860$ The first stage lasting 2-3 years is characterised by a reduced pre-pubertal growth speed; stage two is an accelerated growth spurt; and in the final growth-ceasing stage $>20 \%$ of adult final stature is achieved. This final stage normally occurs between the ages of 13-17 years: bone formation exceeds bone reabsorption processes and skeletal mass will increase approximately twofold, with the most critical period being between 14 and 15 years old. 2247485261 Pubescence is known to be a time whern there is an increased incidence of physeal fractures that often coincides with peak height velocity. ${ }^{61}$

A cross-sectional study of 5461 girls aged 11 to 17 (mean age 13.9) years found $2.7 \%$ had a history of stress fracture, often underreported and untreated..$^{62}$ Those subjects who participated in $>16 \mathrm{~h}$ of exercise per week had 1.88 greater odds of developing stress fractures; leanness was also implicated with these fractures. ${ }^{62}$ High-impact sports, for example running or gymnastics presented the greatest risk factor. ${ }^{62}$

Mounting clinical evidence suggests that sports training of sufficient duration and intensity can precipitate pathological changes to the growth plate that may result in growth disturbance. ${ }^{61}{ }^{63}$ Bone growth can be halted through shearing, avulsion and compression forces to produce deformity. ${ }^{61}{ }^{63} 64$ Unlike adults, the physis on the epiphyseal plates in growing youngsters is two to five times weaker than the surrounding connective fibrous tissue. ${ }^{6163} \mathrm{~A}$ force producing a ligamentous tear in an adult is likely to incur more damage in a youngster. ${ }^{61}{ }^{63}$

Some research points to a $75-90 \%$ probability of developing an upper limb injury or overuse syndrome in climbing. ${ }^{65}$ Upper limb injuries, especially to fingers, are ubiquitous in adult climbing compared with injuries of the foot or lower limbs. ${ }^{31}{ }^{66-84}$ The A-2 pulley rupture is a very common sportspecific injury on the volar aspect of the proximal phalanx. ${ }^{71} 7379$

Where reported, high-ability climbers generally experienced more injuries, as routes with a higher grade place increased 


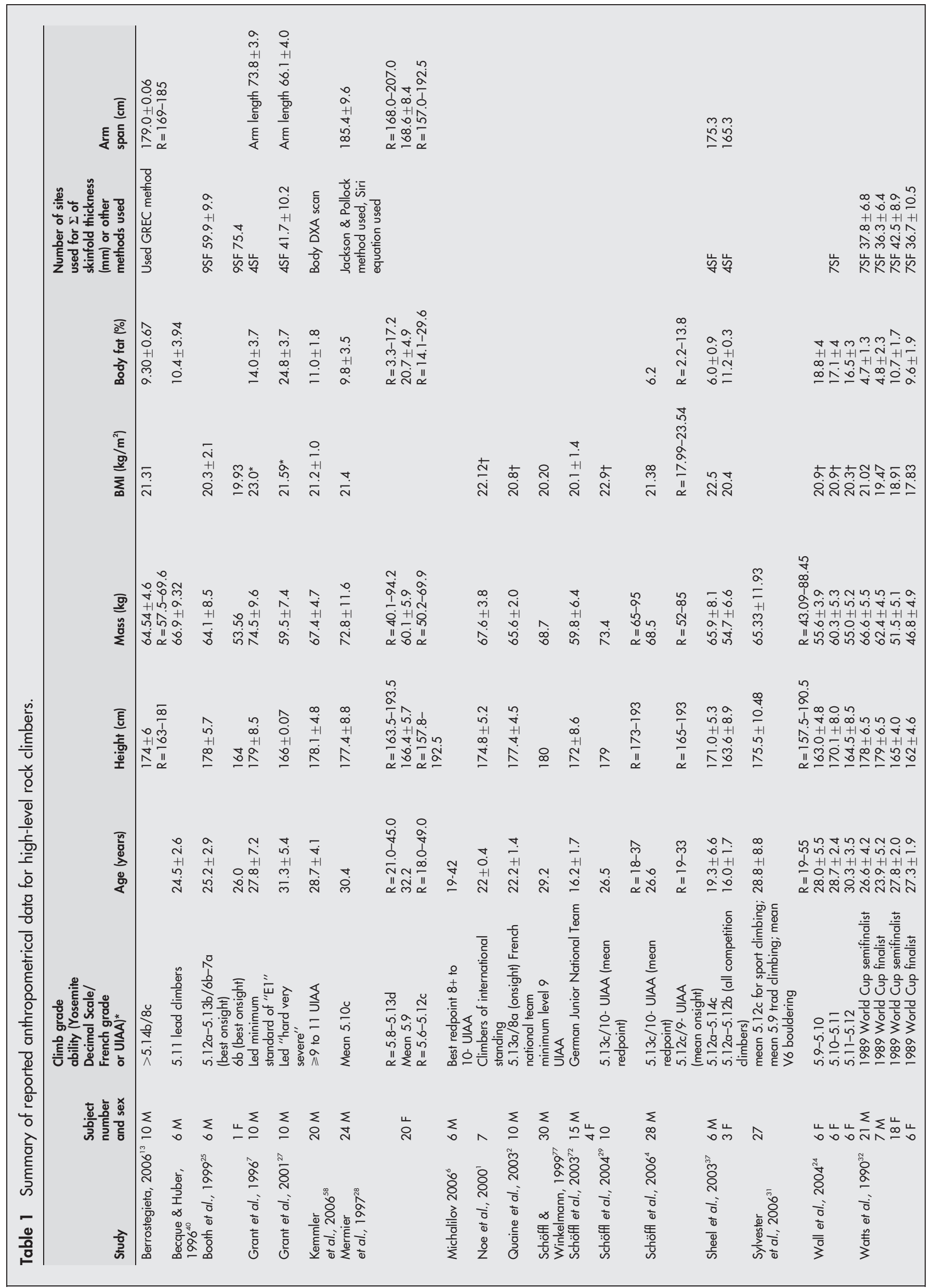




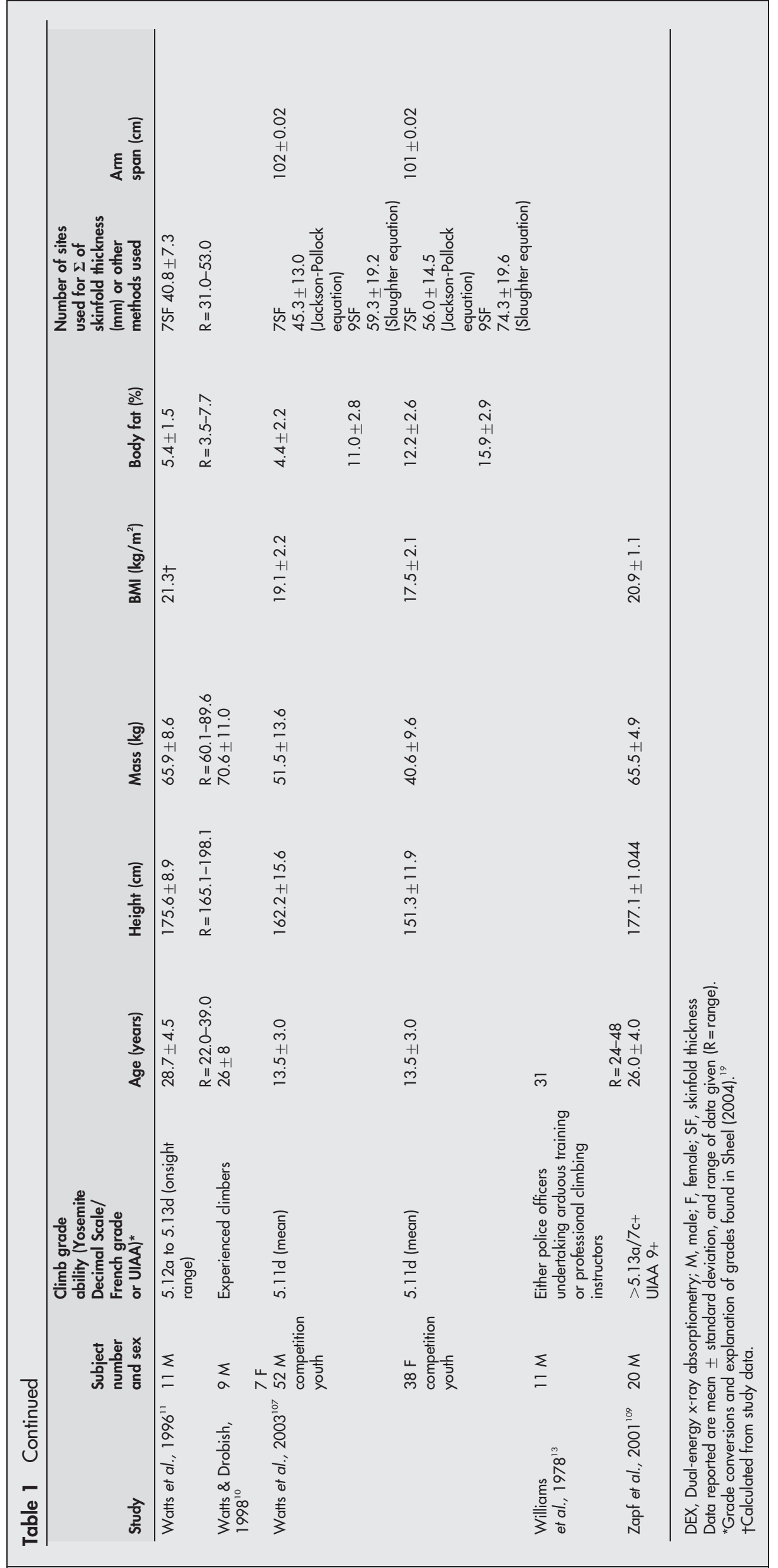

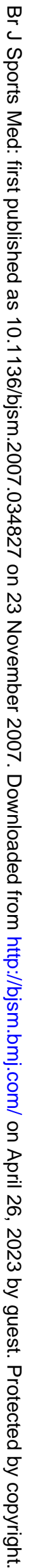


mechanical stresses and weight-bearing loads to the fingers. For example, an elite climber may be required to support their body using one or two fingers on difficult routes. Small handholds requiring the "crimp" position exert the greatest compressive force to finger joint cartilage, compared with the "open hand" position that is more protective. ${ }^{33} 85$ Using radiographic evaluation, Rohrbough et al. found a significantly higher ( $p=0.010$ to 0.036 ) osteoarthritis scores in five specific finger joint areas of experienced climbers $(n=65$, age $=37.5$ years, climb experience $=19.8$ years, grade $=5.12$ c) compared with non-climbing age-matched controls. ${ }^{85}$ The overall osteoarthritis prevalence between both groups was not significant. ${ }^{85}$

Such evidence suggests there may be many unreported injuries in young climber's fingers, especially those who can climb identical grades to those achieved by elite adult climbers.

\section{Injuries to pubertal climbers' hands}

Hochholzer and Schöffl presented 24 case studies on pubertal climbers (age $14.5 \pm 0.9$ years, 23 male, one female) with history of finger pain. ${ }^{22}$ Subjects experienced epiphyseal fractures on the proximal interphalangeal joint of the third or fourth finger. The former is typically a climber's strongest finger. No single trauma was associated with any of the fractures. Repeated micro-traumas causing fatigue fractures to affected area were suspected. Medical histories revealed a trend whereby adolescent males undertook intensive finger strength training to compensate for their increased weight gain following a growth spurt. Climbers who delayed reporting joint pain, ignored medical advice and continued to train intensively, especially on the "Campusboard", experienced permanent deformity of the affected finger with some loss of range of motion, as seen in figs 2 and 3.

The long-term effects of high impact and stress on the finger joints of young climbers cannot be predicted, as there are too few longitudinal studies to understand whether such changes may lead onto the early onset of osteoarthritis. ${ }^{22} 318687$ This type of permanent damage could adversely affect a climber's quality of life and future competitive career.

\section{BOULDERING COMPETITIONS}

"Bouldering" is ropeless climbing over a short distance that generally involves more intense and sustained anaerobic power moves.

To minimise the risk of digital damage and injury from uncontrolled falls at international bouldering competitions, the UIAA medical commission recently proposed, and the International Council of Competition Climbing accepted, that there should be a minimum age of 16 years for participation; ${ }^{88}$ that competitors should be able to safely fall $3 \mathrm{~m}$ onto a DIN 7914 standard (corresponding to $22 \mathrm{~kg} / \mathrm{m}^{3}$ ) ground mattress a minimum of $30 \mathrm{~cm}$ thick; and that route-setters do not place handholds at the top of route that require great jumps to achieve. ${ }^{89}$ Many competition bouldering climbing teams include

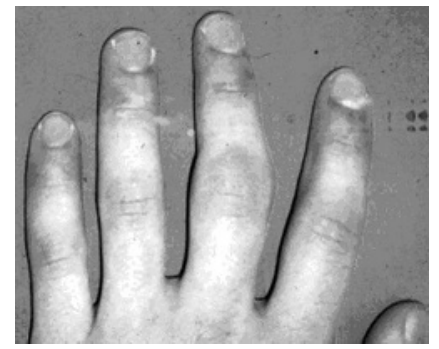

Figure 2 Left hand of 15-year-old male climber who undertook intensive finger strength exercises and ignored medical advice, permanently damaging epiphyseal plate of proximal interphalageal joint in middle finger. Informed consent obtained for publication. (Reproduced from: Hochholzer T, Schöffl V. Epiphyseal fractures of the finger middle joints in young sport climbers. Wilderness Environ Med 2005; 16:4-7, with permission from the Wilderness Medical Society). ${ }^{22}$

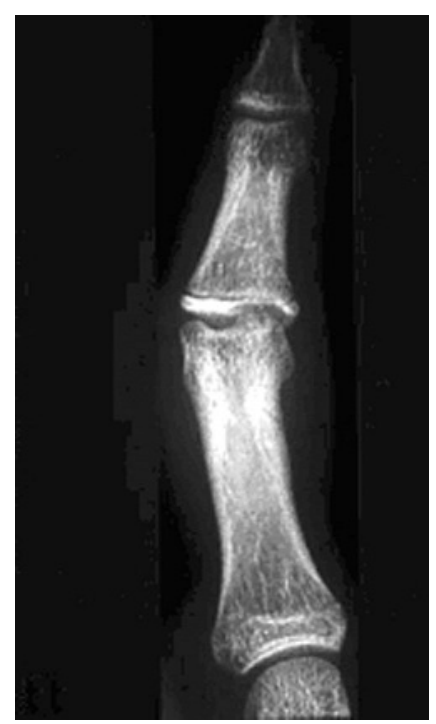

Figure 3 Radiographic image of middle finger from subject in fig 2 . Note $15^{\circ}$ rotation of interphalangeal joint that resulted from ulnar deviation. Informed consent obtained for publication.

(Reproduced from: Hochholzer T, Schöffl V. Epiphyseal fractures of the finger middle joints in young sport climbers. Wilderness Environ Med 2005;16:4-7, with permission from the Wilderness Medical Society). ${ }^{22}$

fall training and ankle stabilisation training, and use "spotters" to limit injuries from inevitable bouldering falls. ${ }^{21}$

\section{KNOWN PHYSIOLOGICAL ADAPTIVE CHANGES TO CLIMBING \\ Climbers' hands}

Adaptive changes that characterise a veteran adult climber's hands have been extensively documented to reveal a doubling in tendon width size, thickened finger phalanges and a tendency to have thicker fingers. ${ }^{22} 3372$ A similar cortical hypertrophy of the bone in the finger phalanges in young rock climbers was found by Schöffl et al. ${ }^{72} 8687$ This hypertrophy was positively correlated to climbing years, training hours and climbing level. ${ }^{72} 8687$

\section{Climbers' feet}

Climbing shoes should facilitate the ability to stand using friction with straight toes and on edges with bent toes with precision and proper contact. ${ }^{16} 33757778$ The majority of climbing foot injuries result from wearing climbing shoes that are unnaturally shaped or too small. ${ }^{76-78}$ High-ability climbers experience more foot deformities and injuries compared with climbers of lower ability due to the common practice of wearing climbing shoes sized smaller than normal street wear shoes (see figs 4 to 7$).^{75} 77$ Only one paper ${ }^{77}$ on young climbers reported shoe sizes for both normal and climbing footwear: the mean was found to be $2.3 \pm 0.73$ Continental sizes smaller in 19 junior competition subjects (Volker Rainer Schöffl, personal communication, 2007).

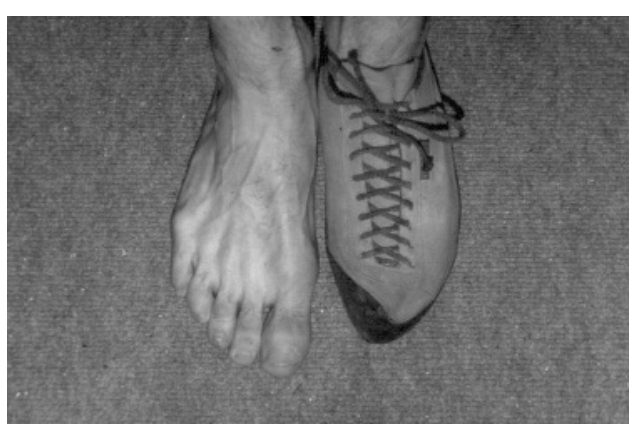

Figure 4 A standing climber's feet bare and wearing climbing shoes. Informed consent obtained for publication. 


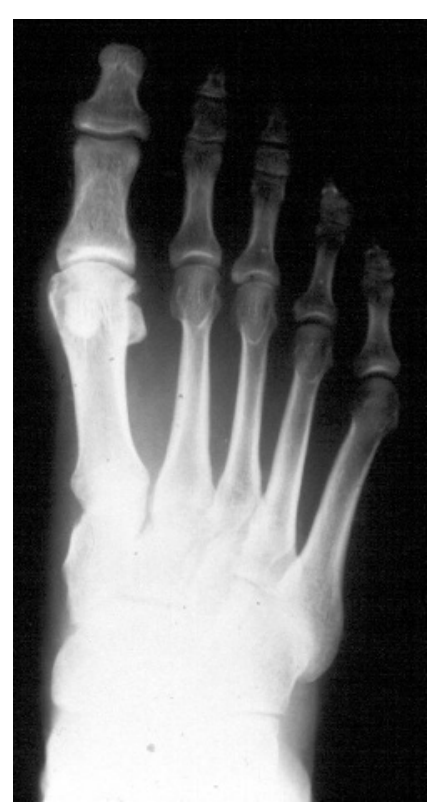

Figure 5 An X-ray of a climber's bare foot while standing. Informed consent obtained for publication.

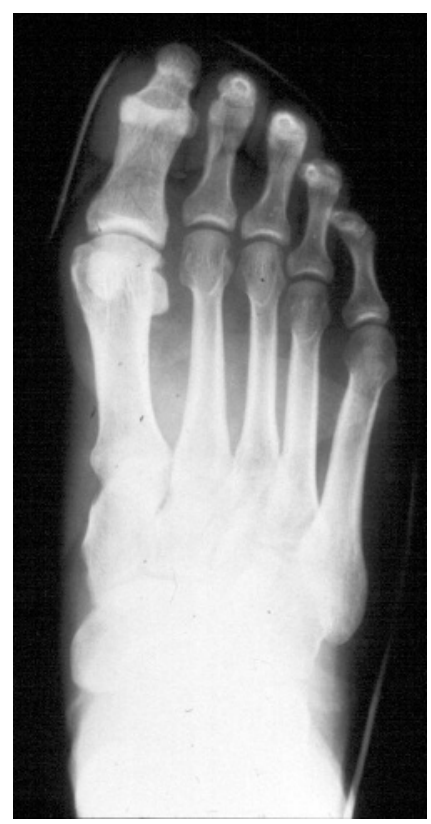

Figure 6 An X-ray of the climber's foot (the same subject as in fig 5) in a climbing shoe. Note "crimping" toes and hallux valgus position of the large toe. Informed consent obtained for publication.

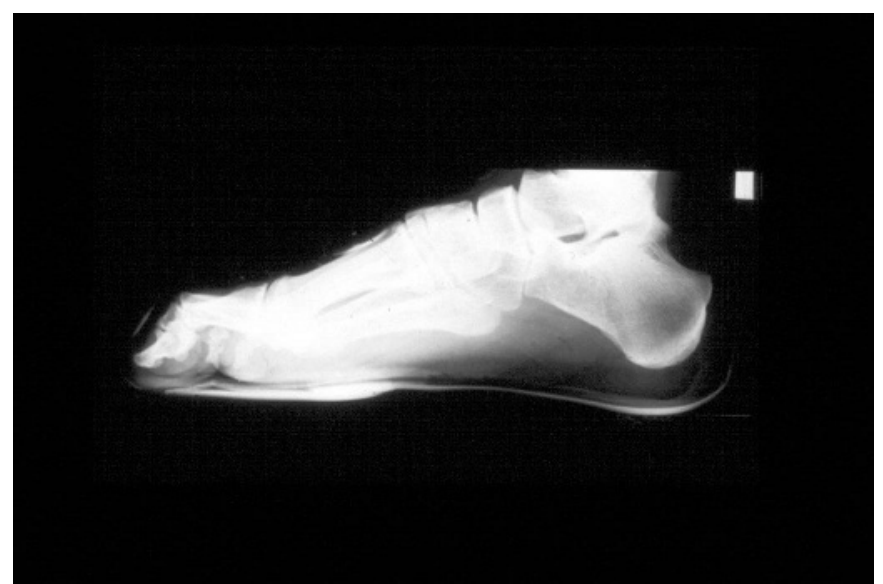

Figure 7 A foot in a climbing shoe. Note that the forefoot does not rest on the head of the metacapalia 1 and 5 as normal but on the "crimping" toes. Informed consent obtained for publication.
Foot length and width increase in a linear fashion from the age of 3 to 12 years in girls and to 15 years in boys, after which growth plateaues. ${ }^{90}$ Foot length and width were also significantly correlated to body height in these 2829 children aged 3 to 18 years with a coefficient of 0.96 to 0.98 for both sexes. ${ }^{90}$ Wearing excessively restrictive climbing shoes is not recommended to help achieve full growth potential and minimise the incidence of localised bouts of acute or chronic pain, injury or permanent deformity. ${ }^{75-78} 9192$ Removing climbing shoes between climbs may also help limit such damage.

\section{Adaptation's of climbers' hearts}

Italian law mandates that athletes at all levels of competition have their hearts screened regularly, normally by echocardiograph. This Italian database is formidable, aptly demonstrated by Corrado et al.' s' ${ }^{93}$ study on 33735 young athletes. Delise et al. ${ }^{38}$ drew upon this database to create five classifications into which different sports could be grouped dependant on common characteristics of cardiovascular involvement. Climbing and sport climbing were categorised as:

sports with "pressure" cardiovascular involvement, characterised by submaximal cardiac output, high to maximal heart rate and moderate to marked increase in peripheral resistances $^{38}$

The dimensions of the left ventricular diastolic cavity in isometric sports have high values for wall thickness relative to the cavity capacity. ${ }^{94}$

From limited metabolic data of short duration obtained on adult climbers, an adult $\mathrm{VO}_{2 \text { peak }}$ is estimated to be $52-$ $55 \mathrm{ml} \cdot \mathrm{kg}^{-1} \cdot \mathrm{min}^{-1}$, averaging $20-25 \mathrm{ml} \cdot \mathrm{kg}^{-1} \cdot \mathrm{min}^{-1}$ during an ascent. $^{5619}$ This reinforces the isometric rather than isotonic aerobic quality ${ }^{95}$ of climbing, and would reflect the climbing sub-discipline tested. ${ }^{24}{ }^{34}$ Bar-Or, designer of the Wingate anaerobic test, found that $\mathrm{VO}_{2}$ was unchanged in children aged 6-15 years and this corresponded to approximately $49 \mathrm{ml} \cdot \mathrm{kg}^{-1} \cdot \mathrm{min}^{-1}{ }^{96}$ Such data suggest that children can almost match an adult climber's $\mathrm{Vo}_{2}$ peak without any additional training, and that aerobic potential is not a limiting factor to climbing performance.

Development of anaerobic potential is more limited in children and will be explored later. ${ }^{97} 98$

\section{Back pain}

There are major differences in the diagnosis of back pain in young athletes versus adults. ${ }^{64}$ The stress fracture of the pars interarticularis at the base of the spine, or spondylolysis, is often overlooked in young athletes. ${ }^{6499}$ Symptoms include a complaint of focal low back pain, although the pain can also extend into the buttock or legs. Sports with causative mechanisms such as lumbar hyperextension and rotation found in rowing, artistic gymnastics and throwing sports record high spondylolysis prevalence rates $(16.88 \%, 16.96 \%$ and $26.67 \%$, respectively) compared with the general population (3.0\% to $8.02 \%) .{ }^{100}$ Climbing also involves these causative mechanisms.

Reports suggest climbing may precipitate the development of spondylolysis, but its prevalence has not been investigated. ${ }^{33}$ Anecdotal evidence in veteran adult climbers of spondylolisthesis has been reported. ${ }^{33}$ Spondylolisthesis refers the overuse deterioration of a spinal disc that causes it to slip out of alignment.

\section{IMPROVED ATHLETIC PERFORMANCE TIMEFRAMES IN YOUNG ATHLETES}

Distinguishing the independent effects of training from those of normal growth and other confounding factors is difficult due 
to the shortage of longitudinal studies. Viru et al.'s ${ }^{101}$ global meta-analysis of 31 studies and 11 reviews of the annual increases and improvements in motor abilities for youngsters, summarised in table 2, was based mainly on cross-sectional data. Viru's timeframes for strength improvements are strongly associated with the latter stages of sexual maturation and specific ontogenetic development, as in the testosteronedependent muscular hypertrophy found in male adolescents. ${ }^{101}$ Sexual maturation is associated with the phenomenon of "outgrowing one's strength". ${ }^{101}$ The rate of improvement in motor abilities declines at ages closely associated with the second and third stages of sexual maturation, and may cease at approximately age 16 years in boys and 14 years in girls. ${ }^{101}$

The mean age of $14.5 \pm 0.9$ years reported in Hochholzer and Schöffl' ${ }^{22}$ case studies of 24 climbers ( 23 adolescent males) with finger fractures coincides with Viru's ${ }^{101}$ timeframes for improvements for strength and speed, "outgrowing one's strength", as well as the critical age between 14 and 15 years old when skeletal mass increases approximately twofold and is at greater risk of injury. ${ }^{4785}{ }^{61}$ The influence of training and rapid growth at this age is further supported by examination of red blood cell count, packed cell volume and haemoglobin concentration in 876 intensely training athletes (age $14.01 \pm 0.06$ years) compared with controls. ${ }^{102}$ All measured variables were reduced more in the athletic group versus controls, and the male athletes experienced the greatest reductions. ${ }^{102}$

\section{DIFFERENCES IN THE YOUNGSTER'S METABOLISM}

Children as young as 12 years old are "metabolic nonspecialists"; they do not exhibit the specialised metabolic response to their sport as occurs in adults. ${ }^{96}{ }^{97} 103-105$ Unlike adults, children metabolise fat, rather than carbohydrate, for energy when undertaking either prolonged or short, intense exercise. ${ }^{96-98} 103$ Until sexual maturation occurs, the quantities of several essential anaerobic enzymes are simply inadequate to sustain isometric contractions and support heavy loading. ${ }^{96-98} 103$ The metabolism of an adult's tendons and ligaments demonstrates oxygen consumption is reduced by 7.5 times compared with skeletal muscles. ${ }^{106}$

Thirst and pain homeostatic feedback mechanisms are immature in children and require careful monitoring. ${ }^{63} 6496104105$

\section{SOMATOTYPE OF CLIMBERS}

Watts $^{5}$ suggests that the shift in the 1990s to adding severe overhangs to competition routes may have resulted in the physiological demands of the sport to favour mesomorphic ectomorphs of a shorter stature. ${ }^{107}$ The rationale offered was that the resistance forces associated with moments would be greater for taller climbers whose distal extremities were further away from their torso's centre of gravity, and the possible increased body mass in taller climbers may result in climbing fatigue being experienced earlier, ${ }^{107}$ as demonstrated in fig 1 .

Some studies suggest that the increased arm span to height ratio in elite climbers may be a selective trait at that level, ${ }^{13} 107$ although other authors suggest trainable variables are more selective of higher climbing ability. ${ }^{4} 19242728$

The biomechanical theory about an ideal height and arm span for climbing has not been investigated, but some racial differences are known to exist. Yun et al. measured 10322 healthy Korean children to determine whether any correlations existed among height, leg length and arm span. ${ }^{108}$ Yun found that arm span in the shortest children never exceeded height, and that in tall boys arm span growth accelerated between puberty to age 17 years and remained increased. ${ }^{108}$ Black people have relatively long limbs, while Asian people tend to have shorter limbs. ${ }^{54}$ Ethnicity is not reported in climbing studies.

The evidence shown in table 1 is inadequate to characterise an elite climber's somatotype at any age, but successful adolescent athletes aged 12-18 years generally exhibit common sport specific somatotyping to a successful adult athlete. ${ }^{46}{ }^{59}$ It may be useful to establish elite adult climbers' somatotyping by measuring the girth, length and breadth of the limbs, and trunk area, body mass and composition, and possibly ethnicity.

\section{SPORTS REQUIRING LEANNESS TO BE COMPETITIVE}

The widespread anecdotal view amongst climbers that reduced body fat improves performance has not been investigated, ${ }^{19}$ although elite climbers often have low levels of body

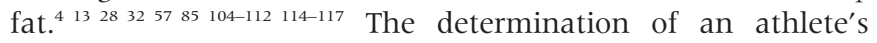
optimal body weight and composition for health and competition should be done individually as they are strongly influenced by age, sex, genetics and the requirements of the sport. ${ }^{46} 113$

The estimated minimum amount of body fat in adults that is compatible with health is $5 \%$ in men and $12 \%$ in women. ${ }^{46}$ Reference tables detailing what the minimum fat percentages should be in growing young athletes are unknown. ${ }^{43} 44113$

Watts $^{\prime 107}$ elegant investigation of 90 competition climbers aged $13.5 \pm 3$ years found that they were at or below the 50th centile for sex- and age-matched normative data and athletic controls when measured for height, weight and body fat $(p<0.01)$. No measures of biological maturity or genetic predictions of final stature were recorded in this or any other

Table 2 Summary of findings adapted from Viru et al. ${ }^{101}$ identifying approximate age periods of accelerated improvement in motor abilities from age 6-18 years

\begin{tabular}{lll}
\hline Accelerated improvement in: & $\begin{array}{l}\text { Boys } \\
\text { Age (years) }\end{array}$ & $\begin{array}{l}\text { Girls } \\
\text { Age (years) }\end{array}$ \\
\hline Speed (sprint running or maximal pedalling rate) & $7-8$ & $8-9$ \\
& $14-15$ & $12-13$ \\
Explosive strength (measuring effectiveness of fast contraction of leg extensor & $7-9$ & $6-8$ \\
muscles) & $13-16$ & $11-12$ \\
PI & $13-16$ & $11-12$ \\
Isometric muscle strength (handgrip, arm pull, pulling strength in shoulders, knee $14-16^{*}$ & $12-13^{*}$ \\
extensor force, clean-and-press) & $14-16$ & $12-13$ \\
PI & $11-15$ & $11-13$ \\
Aerobic endurance & $12-13$ & $11-12$ \\
PI & $7-9$ & $6-8$ \\
Motor development & $12-16$ & $10-14$ \\
Age when motor development ceases before age 18 years & 16 & 14 \\
\hline
\end{tabular}

$\mathrm{Pl}$, peak improvement.

Exercise tests used to determine motor abilities are shown in parentheses.

*No agreement in muscle strength in found in preadolescents. 


\section{What is already known on this topic}

Data on young climbers are rare. Studies revealing the physiological response to various climbing sub-disciplines in adults are limited. Adult studies generally feature males, identification of sport-specific injury and injury patterns, basic anthropometrical data and development of unique sportspecific testing protocols differentiating trainable variables in elite climbers.

\section{What this study adds}

This study initiates an evidence-based foundation to help inform the development of a long-term athletic training programme for dedicated young climbers. It incorporates known physiological developmental issues common to all young athletes alongside known physiological variables in climbing. An elite adult climber's training regimen is inappropriate for an elite young climber, even if they climb or compete on identical routes.

study known to the author on young climbers. It is not known whether these shorter and leaner competitive climbers were the result of selection, training duration and intensity and/or dietary habits.

Failure to attain full genetic height potential may have several different causes..$^{54}$ Pre-pubertal growth is dominated by the accelerated growth of the lower body, while post-pubertal growth is dominated by the accelerated growth of the trunk with some genetic variation..$^{5257}$ Site-specific bone growth deficits may occur for a wide variety of reasons, including exposure of intense training or negative energy balance that can reduce levels of insulin-like growth factor $1.455052-5557$ For example, as gymnasts' high-impact sport-specific training begins pre-pubertally, they can have marked stunting in leglength growth ${ }^{52}$ compared with rhythmic gymnasts and swimmers whose training presents active loading but low impact exposure..$^{505-57}$

Caine et al. ${ }^{55}$ reviewed gymnastic studies from 1966 and found that competitive gymnasts were clearly identified by their attenuated growth that was followed by catch-up growth, though not always reversed, once training was reduced or when following early retirement. Caine suggests regularly plotting growth velocity charts from pre-pubescence and referral for complete evaluation of underlying pathologies whenever height is in the lower fifth percentile or there is a downward trend of growth indices across two major percentile lines..$^{55}$

Watts' study reported that the finalists for both sexes shared similar body fat measurements of $9.6 \pm 1.9 \%$ at age $13.5 \pm 3$ years. ${ }^{107}$ The possible implications of this low body fat pre- and post-pubertally will now be explored. A highly correlated positive relationship was found between total body fat mass and bone mass and size $(\mathrm{p}<0.001)$ in 3082 children by repeating DXA measurements at ages 9.9 and 11.8 years. ${ }^{118}$ In girls, this positive relationship was maintained to pre-pubertal Tanner stage 1 $(\mathrm{p}<0.001){ }^{118}$ Clarke suggests that fat mass may act to increase bone size by stimulating radial, as opposed to longitudinal, bone growth by increasing the rate of periosteal apposition.

In adolescence, the combined or independent factors of maintaining of a negative energy intake and low body fat can alter and delay pubertal development, contribute to metabolic and neuroendocrine aberrations, affect stature, detrimentally affect bone growth and integrity in the short and long-term, increase the risk of injuries including stress fractures, and trigger eating disorders. ${ }^{45} 4649-5254-5762112118$ Disordered or restrictive eating patterns are reported in elite adult climbers. ${ }^{20} 109110113$ Regardless of training volume, aesthetic sports requiring leanness for competition typically have a high incidence of delayed menarche, menstrual dysfunction and eating disorders in both sexes. ${ }^{46} 57112$ Disordered eating, amenorrhea and osteoporosis are the three interrelated components that make up the "female athlete triad". Kahn et al. present a strong case for including osteopenia in the triad definition. ${ }^{116}$ Where one triad component exists, the other interrelated components must also be investigated as the consequences and can be time-dependent, and possibly irreversible. ${ }^{4652} 116$

Other research suggests that the deleterious catabolic and hormonal effects on health and performance of maintaining a negative energy balance and low body fat, especially after an intensive workout, are greater than those posed by the workout itself. $^{46} 57111117$ Lipid and apolipoprotein profiles in young female athletes aged 10 to 15 years may be due to differences in physical activity rather than dietary intake. ${ }^{115}$ Therefore both the timing and appropriateness of the dietary intake are both important factors for health and performance.

\section{CONCLUSIONS}

Based on evidence presented in this review, the following considerations are suggested when designing training programmes for dedicated young climbers:

- Climbers aged $<16$ years should not undertake intensive finger strength training and cannot not participate in international bouldering competitions.

- A force producing a ligamentous tear in an adult is likely to incur more damage in a growing youngster as the physis on their epiphyseal plates is two to five times weaker than the surrounding connective fibrous tissue.

- The final pubescent growth spurt is associated with an increased risk of injuries and physeal fractures.

- Up to about 12 years old, children have a limited capacity to develop an adaptive metabolic response to specific training, but possess an accelerated ability for motor development.

This suggests the emphasis of training should be on climbing an increased volume and diversity of climbing routes to improve fluency and mechanical efficiency of climbing techniques, as opposed to increasing intensity.

- Wearing excessively restrictive climbing shoes is not recommended in growing feet to help prevent foot injuries and deformities. Regular record-keeping of street wear and climbing shoe size may be a useful strategy up to a minimum age of 15 years.

- Growth velocity charts and measures of body fat should be sensitively and regularly plotted. If possible, menarche age and cycle details should also be collected. Referral for complete evaluation of underlying pathologies should be undertaken whenever height is in the lower fifth percentile or there is a downward trend of growth indices across two major percentile lines. This may also reveal whether a climber's growth curve is characteristic of an early maturer, as in a swimmer, or that of a late maturer, as in a gymnast.

- Climbers should be educated in the importance of an appropriate diet and timing of this intake on health and performance.

- The incidence of spondylolysis has not been documented and warrants investigation.

- The age at which a climber should specialise in climbing is unknown. 
- Knowledgeable and qualified personnel should carefully monitor training. Where training intensity is increased, it should reflect safe and efficacious exercises for a given sex and biological age, independent of the competition calendar.

- More research on young climbers is needed.

\section{ACKNOWLEDGEMENTS}

The author thanks Steve Gorton for the photograph of a young competition climber

\section{Authors' affiliations \\ Audry Birute Morrison, Nutritionist, London, UK \\ Volker Rainer Schöffl, Department of Trauma and Orthopedic Surgery, Klinikum Bamberg, Bamberg, Germany; Department of Trauma Surgery and Orthopedic Surgery, Friedrich Alexander University of Erlangen- Nuremberg, Germany}

Funding: None.

Competing interests: None.

\section{REFERENCES}

1 Noe F, Quaine F, Martin L. Influence of steep gradient supporting walls in rock climbing: biochemical analysis. Gait Posture 2001;13:86-94.

2 Quaine F, Vigouroux L, Martin L. Finger flexors fatigue in trained rock climbers and untrained sedentary subjects. Int J Sports Med 2003;24:424-7.

3 Quaine F, Vigouroux L. Maximal resultant four fingertip force and fatigue of the extrinsic muscles of the hand in different sport climbing finger grips. Int J Sports Med 2004;25:634-37.

4 Schöffl V, Möckel F, Köstermeyer G, et al. Development of a performance diagnosis of the anaerobic strength endurance of the forearm flexor muscles in sport climbing. Int J Sports Med 2006;27:205-11.

5 Watts PB. Physiology of difficult rock climbing. Eur J App/ Physiol 2004;91:361-72.

6 Michailov M. Evolvement and experimentation of a new interval method for strength endurance development, In: Moritz EF, Haake S, eds. The engineering of Sport 6, Volume 2, Developments for disciplines. New York: Springer Science and Business Media, 2006

7 Grant S, Hynes V, Whittaker A, et al. Anthropometric, strength, endurance and flexibility characteristics of elite and recreational climbers. J Sports Sci 1996;14:301-09.

8 Schweitzer A. Biomechanical properties of the crimp position in rock climbers. J Biomech $2001 ; 34: 217-23$.

9 Koukoubis TD, Cooper LW, Glisson RR, et al. An electromyographic study of arm muscles during climbing. Knee Surg Sports Trau Manol Arthrosc 1995; 3:121-124.

10 Watts PB, Drobish KM. Physiological responses to simulated rock climbing at different angles. Med Sci Sports Exerc 1998;30:1118-1122.

11 Watts PB, Newbury V, Sulentic J. Acute changes in handgrip strength, endurance, and blood lactate with sustained sport rock climbing. I Sports Med Phys Fitness 1996;36:255-260.

12 Schöffl V, Möckel F, Köstermeyer G. Entwicklung einer sportartspezifischen Leistungsdiagnostik der laktaziden Kraftausdaver der Unterarmbeugemuskulatur im Sportklettern. Österreichisches J für Sportmedizin 1997:1:30-38, Article in German.

13 Berrostegieta Jl. Relation between specific force tests and chained degree in high level sport climbers. In: Moritz EF, Haake S, eds. The engineering of Sport 6, Volume 2. Developments for disciplines. New York: Springer Science and Business Media, 2006

14 Mace R. Physiological arousal in climbers. Physical Education Review 1979;2: 141-49.

15 Williams E, Taggert $\mathrm{P}$, Carruthers $M$. Rock climbing: observations on heart rate and plasma catecholamines and the influence of oxprenolol. Br J Sports Med 1978; 12:125-28.

16 Goddard D, Neumann U. Performance rock climbing. Mechanicsburg, PA: Stackpole Books, 1993.

17 Wadsworth, BJ. Piaget's theory of cognitive and affective development. White Plains, NY: Longman, 1996.

18 Feher P, Meyers MC, Skelly WA. Psychological profile of rock climbers: state and trait attributes. J Sport Behavior 1998;21:167-81.

19 Sheel AW. Physiology of sport rock climbing. Br J Sports Med 2004;38:355-59.

20 UIAA - International Climbing and Mountaineering Federation. http:// www.viaaclimbing.com/ (accessed 2 November 2006).

21 Schöffl V, Küpper T. Injuries at the 2005 World Championships in Rock Climbing. Wilderness Environ Med 2006;17:187-90.

22 Hochholzer T, Schöffl V. Epiphyseal fractures of the finger middle joints in young sport climbers. Wilderness Environ Med 2005;16:4-7.

23 Capital climbing competition. http://www.capitaldimbingfestival.co.uk/ CCF\%20registration\%20form.doc (accessed 24 November 2006).

24 Wall CB, Starek JE, Fleck SJ, et al. Prediction of indoor climbing performance in women rock climbers. J Strength Cond Res 2004;18:77-83.
25 Booth J, Marino F, Hill C, et al. Energy specificity of rock climbing and aerobic capacity in competitive sport rock climbers. Br J Sports Med 1999:33:14-18.

26 Watts PB, Jensen RL. Reliability of peak forces during a finger curl motion common in rock climbing. Measurements in Physical Education and Exercise Science 2003:7:263-67.

27 Grant S, Hasler T, Davies C, et al. A Comparison of the anthropometric, strength, endurance, and flexibility characteristics of female elite and recreational climbers and non-climbers. J Sports Sci 2001;19:499-505.

28 Mermier CM, Robergs RA, McMinn SM, et al. Energy expenditure and physiological responses during indoor rock climbing. Br J Sports Med 1997;31:224-28.

29 Schöffl V, Klee S, Strecker W. Evaluation of physiological standard pressures of the forearm flexor muscles during sport specific ergometry in sport climbers. Br J Sports Med 2004;38:422-25.

30 Watts PB, Gannon E, Kobeinia R, et al. EMG Reponses in rock climbing using six hand positions. Med Sci Sports Exerc 1999;31:S169.

31 Sylvester AD, Christensen AM, Kramer PA. Factors influencing osteological changes in the hands and fingers of rock climbers. J Anat 209:597-609.

32 Watts P, Martin D, Durtsche S. Anthropometric characteristics of elite male and female competitive rock climbers. Med Sci Sports Exerc 1990;22:S402.

33 Hochholzer T, Schoeffl V, Lightner Jr S, eds. One move too many.... Ebenhausen: Lochner-Verlag, 2003. English version.

34 Draper N, Bird EL, Coleman I, et al. Effects of active recovery on lactate concentration, heart rate and RPE in climbing. J Sports Sci Med 2006;5:97-115.

35 Gandevia SC. Central factors in human fatigue. Physiol Rev 2001;81:1726-78.

36 American College of Sports Medicine. ACSM's guidelines for exercise testing and prescription 6th edn. Philadelphia, PA: Lippincott Williams \& Wilkins, 2000

37 Sheel W, Seddon N, Knight A, et al. Physiological responses to indoor rockclimbing and their relationship to maximal cycle ergometry. Med Sci Sports Exerc 2003:35:1225-31.

38 Delise $\mathbf{P}$, Guiducci U, Zeppilli $\mathrm{P}$, et al. Cardiological guidelines for competitive sports eligibility. Ital Heart J 2005;6:661-702.

39 Billat V, Palleja $\mathrm{P}$, Charlaix $\mathrm{T}$, et al. Energy specificity of rock climbing and aerobic capacity in competitive sport rock climbers. J Sports Med Phys Fitness 1995;35:20-24.

40 Becque MD, Huber L. Exertional intensity and energy expenditure of sport rock climbing 1244. Med Sci Sports Exerc 1996;8:S209.

41 Ferguson RA, Brown MD. Arterial blood pressure and forearm vascular conductance responses to sustained and rhythmic isometric exercise and arterial occlusion in trained rock climbers and untrained sedentary subjects. Eur J Appl Physiol 1997;76:174-80

42 Wilson G. Limitations to the use of isometric testing in athletic assessment, In: Gore CJ, ed. for Australian Sports Commission. Physiological tests for elite athletes. Champaign, IL: Human Kinetics, 2000.

43 Pietrobelli A, Faith MS, Allison DB, et al. Body mass index as a measure of adiposity among children and adolescents: a validation study. J Pediatr 1998;132:204-10.

44 Rolland-Cachera MF, Sempe M, Guilloud-Bataille M, et al. Adiposity indices in children. Am J Clin Nutr 1982;36:178-84.

45 Eveleth PB, Tanner JM. Worldwide variation in human growth, 2nd edn. Cambridge: Cambridge University Press, 1991.

46 American College of Sports Medicine, American Dietetic Association, Dietitians of Canada. Nutrition and athletic performance. Med Sci Sports Exerc 2000;32:2130-45.

47 Rogol AD, Clark PA, Roemmich JN. Growth and pubertal development in children and adolescents: effects of diet and physical activity. Am J Clin Nutr 2000;72:521S-528S.

48 Lima F, Falco V, Baima J, et al. Effect of impact load and active load on bone metabolism and body composition of adolescent athletes. Med Sci Sports Exerc $2001 ; 33: 1318-23$

49 Damsgaard R, Bencke J, Muller J. IGF-1 levels in 188 adolescents during two years of training at a competitive level. J Clin Endocrinol Metab 2001;33:S288.

50 Peltenburg AL, Erich WB, Bernink MJ, et al. Biological maturation, body composition, and growth of female gymnasts and control groups of schoolgirls and girl swimmers aged 8 to 14 years: a cross-sectional survey of 1064 girls. Int J Sports Med 1984;5:36-42.

51 Rubin K. Pubertal development and bone. Curr Opin Endocrinol Diab 2000;7:65-70

52 Weimann E. Gender-related differences in elite gymnasts: the female athlete triad. J Appl Physiol 2002;92:2146-52.

53 Theintz GE, Howald H, Weiss U, et al. Evidence for a reduction of growth potential in adolescent female gymnasts. J Pediatr 1993;122:306-13.

54 Rimoin DL, Borochowitz Z, Horton WA. Short stature - physiology and pathology [medical progress]. West J Med 1986;144:710-21.

55 Caine $D$, Lewis $R, O^{\prime}$ Connor $P$, et al. Does gymnastics training inhibit growth in females? Clinical J of Sport Med 2001;11:260-70.

56 Georgopoulos NA, Markou KB, Theodoropoulou A, et al. Growth and pubertal development in elite female rhythmic gymnasts. J Clin EndocrinolMetab 1999:84:4525-30.

57 Theodorpoulou A, Markou KB, Vagenakis GA, et al. Delayed but normally progressed puberty is more pronounced in artistic compared with rhythmic elite gymnasts due to the intensity of training. J Clin Endocrinol Metabol 2005;90:6022-7.

58 Kemmler W, Roloff I, Baumann $\mathrm{H}$, et al. Effect of exercise, body composition, and nutritional intake on bone parameters in male elite rock climbers. Int J Sports Med 2006;27:653-59.

59 Baxter-Jones ADG, Thompson AM, Malina RM. Growth and maturation in elite young female athletes. Sports Med Arthrosc Rev 2002;10:42-9. 
60 Georgopoulos NA, Markou KB, Theodoropoulou A, et al. Growth, pubertal development, skeletal maturation and bone mass acquisition in athletes. Hormones (Athens) 2004;3:233-43.

61 Caine D, DiFiori J, Maffulli N. Physeal injuries in children's and youth sports: reasons for concern? Br J Sports Med 2006:40:749-470.

62 Loud KJ, Gordon CM, Micheli L, et al. Correlates of stress fractures among preadolescent and adolescent girls. Pediatrics 2005;115:399-406.

63 Maffulli N, Bruns W. Injuries in young athletes. Eur J Pediatr 2000; 159:59-63.

64 Micheli LJ, Wood R. Back pain in young athletes. Significant differences from adults in causes and patterns. Arch Pediatr Adolesc Med 1995; 149:15-18.

65 Wright DM, Royle TJ, Marshall T. Indoor rock climbing: who gets injured? Br J Sports Med 2001;35:181-85.

66 Paige TE, Fiore DC, Houston JD. Injury in traditional and sport rock climbing Wilderness Environ Med 1998:9:2-7.

67 Rohrbough JT, Mudge MK, Schilling RC. Overuse injuries in the elite rock climber. Med Sci Sports Exerc 2000;32:1369-72.

68 Rooks MD. Rock climbing injuries. Sports Med 1997;23:261-70.

69 Schad R. Analysis of climbing accidents. Accid Anal Prev 2000;32:391-6.

70 Schadle-Schardt W. Die zeitliche Gestaltung von Belastung und Entlastung im Wettkampfklettern als Element der Trainingssteuerung. Leistungssport 1998;1:23-28, Article in German.

71 Schöffl V, Hochholzer T, Winkelmann H-P, et al. Pulley injuries in rock climbers. Wilderness Environ Med 2003; 14:94-100.

72 Schöffl V, Hochholzer T, Imhoff A. Radiographic changes in the hands and fingers of young, high-level climbers. Am J Sports Med 2004;32:1688-94.

73 SchöffI VR, Schöffl I. Injuries to the finger flexor pulley system in rock climbers: current concepts. J Hand Surg [Am] 2006:31:647-54.

74 Straub G. Probleme des Bewegungsapparates bei sportkletterern - eine Ubersciht. Wien Med Wschr 2000;150:186-90, Article in German.

75 Killian RB, Nishimoto GS, Page JC. Foot and ankle injuries related to rock climbing. The role of footwear. J Am Podiatr Med Assoc 1998;8:365-74.

76 Peters P. Nerve compression syndromes in sport climbers. Int J Sports Med 2001:22:611-17

77 Schöffl V, Winkelmann H-P. Fußdeformitäten bei Sportkletterern - foot deformations in sport climbers. Dtsch Z Sportmed 1999;50:73-76.

78 van der Putten EP, Snijders CJ. Shoe design for prevention of injuries in sport climbing. Appl Ergonomics 2001;32:379-87.

79 Schöffl V, Schöffl I. Finger pain in rock climbers: reaching the right differential diagnosis and therapy. J Sports Med Phys Fitness 2007;47:70-8.

80 Bollen SR. Injury to the A2 pulley in rock climbers. J Hand Surg [Br] 1990; 15B:268-70

81 Klauser A, Frauscher F, Bodner G, et al. Finger pulley injuries in extreme rock climbers: depiction with dynamic US. Radiology 2002;222:755-761.

82 Logan AJ, Makwana N, Mason G, et al. Acute hand and wrist injuries in experienced rock climbers. Br J Sports Med 2004;38:545-48.

83 Logan AJ, Mason G, Dias J. Can rock climbing lead to Dupuytren's disease? Br J Sports Med 2005;39:639-44.

84 Pfeiffer C, Messner K, Scherer R, et al. Injury patterns and overuse syndrome in young sport climbers. Wien Klein Wochenschr 2000;112:965-72.

85 Rohrbough JT, Mudge MK, Schilling RC, et al. Radiographic osteoarthritis in the hands of rock climbers. Am J Orthop 1998;27:734-8.

86 Schöffl V, Hochholzer Th, Karrer A, et al. Fingerschäden jugendlicher Leistungskletterer - Vergleichende Analyse der deutschen Jugendnationalmannschaft sowie einer gleichaltrigen Vergleichsgruppe von Freizeitkletterern. Disch Z Sportmed 2003:54:317-22, Article in German.

87 Schöffl V, Hochholzer T, Imhoff A, et al. Radiographic adaptations to the stress of high-level rock climbing in junior athletes: a-5 year longitudinal study of the german junior national team and a group of recreational climbers. Am J Sports Med Sept 142006

88 Schöffl V, Schlegel Ch. Statement Competition Climbing. MedCom UIAA, 10/ 2000. UIAA - International Climbing and Mountaineering Federation. http:// www. viaadimbing.com/ (accessed 2 November 2006).

89 Schöffl V, Schlegel Ch. Statement International Boulder Competitions in Youths. MedCom UIAA 1/2004. UIAA - International Climbing and Mountaineering Federation. http://www.viaadimbing.com/ (accessed 2 November 2006).

90 Cheng JCY, Leung S, Leung AKL, et al. Change of foot size with weightbearing; a study of 2829 children aged 3 to 18 years of age. Clin Orthop Relat Res 1997:342:123-31.

91 Pridalova M, Riegerova Jarmilla. Child's foot morphology. Acta Univ Palacki Olomuc Gymn 2005;35:75-84.

92 Riegerova J, Zeravova M. Pestukova M. Analysis of morphology of foot in Moravian male and female students in the age infans 2 and juvenils. Acta Univ Palacki Olomuc Gymn 2005;35:69-72.

93 Corrado D, Basso C, Schiavon M, et al. Screening for hypertrophic cardiomyopathy in young athletes. N Engl J Med 1998;339:364-69.

94 Spirito P, Pelliccia MD, Proschan A, et al. Morphology of the "athlete's heart" assessed by echocardiography in 947 elite athletes representing 27 sports. Am J Cardio 1994;74:802-6.

95 Gibbons RJ, Balady GJ, Bricker JT, et al. ACC/AHA 2002 guideline update for exercise testing: summary article: a report of the ACC/AHA Task Force on Practice Guidelines (Committee to Update 1997 Exercise Testing Guidelines). Circulation 2002;106:1883-92.

96 Bar-Or O. Pediatric sports medicine for the practitioner. New York: SpringerVerlag, 1983

97 Bar-Or O. Children: lower anaerobic power, testing, puberty, and carryover to adulthood. In: Skinner JS, ed. Future directions in exercise/sport research. Champaign, IL: Human Kinetics, 1989.
98 Kaczor JJ, Ziolkowski W, Popinigis J, et al. Anaerobic and aerobic enzyme activities in human skeletal muscle from children and adults. Pediatr Res 2005:57:331-35.

99 Miller SF, Congeni J, Swanson K. Long-term functional and anatomical followup of early detected spondylolysis in young athletes. Am J Sports Med 2004:32:928-33.

100 Soler T, Calderon MD. The prevalence of spondylolysis in the Spanish elite athlete. Am J Sports Med 2000;28:57-62

101 Viru A, Loko J, Volver A, et al. Age periods of accelerated improvement of muscle strength, power, speed and endurance in the age interval 6-18 years. Biol Sport 1998;15:211-27.

102 Boyadjiev N, Taralov Z. Red blood cell variables in highly trained pubescent athletes: a comparative analysis. Br J Sports Med 2000;34:200-4.

103 Bar-Or O. New and old in pediatric exercise physiology. Int J Sports Med 2000;2:S1 13-6

104 Kennedy WL, Chiu P. Influence of age on thirst and fluid intake. Med Sci Sports Exerc 2001;33:1524-32.

105 Bar-Or O. Thermoregulation, fluid and electrolytes in the young athlete. In: Smith NJ, eds. Sports related health concerns in pediatrics, chapter 9. American Academy of Pediatrics, 1983

106 Sharma P, Maffulli N. Tendon Injury and Tendinopathy: healing and repair. $J$ Bone Joint Surg Am 2005;87:187-202.

107 Watts PB, Joubert LM, Lish AK, et al. Anthropometry of young competitive sport rock climbers. Br J Sports Med 2003;37:420-424.

108 Yun DJ, Yun DK, Chang YY, et al. Correlations among height, leg length and arm span in growing Korean children. Ann Hum Biol 1995;22:443-38.

109 Zapf J, Fichtl B, Wielgoss S, et al. Maconutrient intake and eating habits in elite rock climbers. Med Sci Sports Exerc 2001;33:S72.

110 Zapf J. A few points about nutrition and climbing. In: Hochholzer T, Schoeffl V Lightner Jr S, eds. One move too many... Ebenhausen: Lochner-Verlag, 2003.

111 Deutz RC, Benardot D, Martin DE, et al. Relationship between energy deficits and body composition in elite female gymnasts and runners. Med Sci Sports Exerc 2000;32:659-68.

112 Torstveit MK, Sundgot-Borgen J. Participation in leanness sports but not training volume is associated with menstral dysfunction: a national survey of 1276 elite athletes and controls. Br J Sports Med 2005;39:141-7.

113 Muller W. A Scientific approach to address the problem of underweight athletes. A case study of ski jumping. Med Sci Sports Exerc 2002;34:124.

114 Damsgaard R, Bencke J, Malthesen G, et al. Body proportions, body composition and pubertal development of children in competitive sports. Scand J Med Sci Sports 2001;11:54-60.

115 Zonderland ML, Erich WB, Peltenburg AL, et al. Nutrition of premenarcheal athletes: relation with lipid and apolipoprotein profiles. Int J Sports Med 1985;6:329-35.

116 Khan KM, Liu-Ambrose T, Sran MM, et al. New criteria for female athlete triad syndrome? Br J Sports Med 2002;36:10-13.

117 Ivy J, Portman R. Nutrient timing; the future of sports nutrition. North Bergen, NJ: Basic Health Publications, 2003

118 Clarke EM, Ness AR, Tobias JH, the Avon Longitudinal Study of Parents and Children Study Team. Adipose tissue stimulates bone growth in prepubertal children. J Clin Endocrinol Metab 2006;91:2534-41.

\section{COMMENTARY 1 .............}

The authors have reviewed the physiological responses caused by load during rock climbing in young athletes. They focus particularly on preventive aspects of this fantastic sport. As a climber and as specialist who regularly gives lectures about this topic, especially on preventative aspects for children and adolescents, I welcome such a review, which will be especially valuable for colleagues who do not specialise in this area and who are unable to read all the literature on rock climbing.

Thomas Küpper

Technical University of Aachen, Institute for Aerospace Medicine, Aachen Germany; TKuepper@ukaachen.de

\section{COMMENTARY 2}

The paper is an excellent overview of high clinical importance. The first author is an expert in climbing herself and therefore the paper is a recommendable source of information for orthopaedic surgeons as well as general practitioners. The need for further investigations and professional medical care for young climbers should be emphasised. The authors' observations concerning physical injuries and malnutrition can be confirmed by our own findings.

Gunther Straub

Diakonissen Krankenhaus, Linz, Austria; g.straub@diakoniewerk.ał 


\section{Corrections}

Morrison AB, Schöffl VR. Review of the physiological responses to rock climbing in young climbers (BrJ Sports Med 2007;41:852-861). This paper was published in print with an incorrect doi of $10.1136 / \mathrm{bjsm} .2007 .034827$. The correct doi is $10.1136 / \mathrm{bjsm} .2006 .034827$.

Br J Sports Med 2011;45:184. doi:10.1136/bjsm.2006.034827 